\title{
Psalm 89 and the Logical Problem of Evil: A Comparative-philosophical Perspective ${ }^{1}$
}

\author{
JACO GERICKE (NORTH-WEST UNIVERSITY)
}

\begin{abstract}
This study takes as its starting point the consensus in research on the relationship between divine attributes and suffering in Psalm 89 which holds that some of the beliefs expressed in verses 39-52 contradict those in 1-38(53). In an attempt to address a related gap in the research in a new and supplementary way, a comparativephilosophical perspective is offered regarding the reasoning operative within the Psalm's associated religious language. As counterpart, the so-called "Logical Problem of Evil" (LPE) in analytic philosophy of religion was identified. Conceptual and correlation-relations in Psalm 89 are clarified through correlation and contrast. The study argues that the logical status of the beliefs involved, as contradiction, makes more sense if interpreted as part of the protocol when prayer and poetry have to satisfy the conditions of a possible atheodicy. Thus, restating the Psalm's associated content on its own terms, even if not in them, contributes to our understanding of why certain states of
\end{abstract}

* Submitted: 17/02/2021; peer-reviewed: 16/04/2021; accepted: 23/04/2021. Jaco Gericke, "Psalm 89 and the Logical Problem of Evil - A Comparative-philosophical Perspective," Old Testament Essays 34 no. 1 (2021): 300 - 327. DOI: https://doi.org/10.17159/2312-3621/2021/v34n1a17.

1 Once upon a time, there was a first-year theology student. In the course introducing the Book of Psalms, he asked the professor what he considered the most difficult of all the Psalms (to understand). The professor simply responded with "Psalm 89." The student, naïve and idealistic and zealous without knowledge resolved to come up with a solution to whatever was assumed to be problematic about this text. Twenty-seven years later, though not following in the footsteps of the professor and other teachers or colleagues, all of whom have contributed so much to research on the Psalter, I wish to dedicate this article to them all. As for some of their many related works, those I am able to recall as having made a distinct impression include, among others, Willem S. Prinsloo, "Psalm 88: The Gloomiest Psalm?" Old Testament Essays 5 (1992): 332-345; Dirk J. Human. Psalms and Mythology (London: T \& T Clark, 2007); Gert T.M. Prinsloo, "Analysing Old Testament Poetry: An Experiment in Methodology with Reference to Psalm 126," Old Testament Essays 5/2 (1992): 225-251; and Phil J. Botha, "Psalm 108 and the Quest for Closure to the Exile," Old Testament Essays 23/3 (2010): 574-596. Lastly yet importantly, I would like to express my heartfelt thanks and condolences to the once-omniscient young student who, after decades of procrastination and digression, finally got around to taking up the challenge on his own terms. 


\section{affairs in the world of the text are the way they are, or why they are at all.}

KEYWORDS: Psalm 89, suffering, divine attributes, comparative philosophy (of religion), problem of evil, atheodicy

\section{A INTRODUCTION AND BACKGROUND}

The idea that certain beliefs about suffering appear to be incoherently related to certain attributes of YHWH in the variety of associated theological assumptions in the Old Testament (OT) is a familiar theme in biblical scholarship. ${ }^{2}$ What can be considered less familiar, or at least are so overt that they appear covert, are the supervening religious-philosophical presuppositions, problems and perspectives of interpreters of the OT when making use of originally philosophical-theological concepts, concerns and categories. It goes without saying that an uncritical adoption of these exposes one to the risk of the associated hermeneutical and exegetical fallacies as applicable to historicallyconscious descriptive approaches to restating the meaning of religious language on the texts' own terms, even if not in them. Nonetheless, without knowing it, both academic and lay readers of the OT can no longer think of YHWH's assumed relation to suffering without being, to some extent, aware of what is implied by the question of "why bad things happen to good people" (or viceversa: "why good things happen to bad people"). The philosophical-theological coining of the correlating conundrum currently most in vogue when coherencyrelation complications happen to contested concepts in conjunctive conditional constructions is found in what some analytic philosophers of religion refer to as the "Logical Problem of Evil" (LPE), which says, ${ }^{3}$

2 See representatively, inter alia, James L. Crenshaw, Defending God: Biblical Responses to the Problem of Evil (New York: Oxford University Press, 2005). Anthony J. Tambasco, The Bible on Suffering: Social and Political Implications (New York: Paulist, 2001), and classically, Klaus Koch, "Is There a Doctrine of Retribution in the Old Testament?" in Theodicy in the Old Testament (ed. James L. Crenshaw; London: SPCK, 1993), 57-87. On related foci, see Terrence E. Fretheim, The Suffering of God: An Old Testament Perspective (Philadelphia: Fortress Press, 1984); Erhard Gerstenberger and Wolfgang Schrage, Suffering (trans. John E. Steely; Nashville: Abingdon, 1977). For the ancient Near Eastern background as example, see Ronald J. Williams, "Theodicy in the Ancient Near East," in Theodicy in the Old Testament (ed. James L. Crenshaw; London: SPCK, 1993), 42-56.

3 For an introduction specifically dedicated to this form of the problem of evil, see James R. Beebe, "Logical Problem of Evil," n.p. The Internet Encyclopedia of Philosophy. Cited 4 November 2020. Online: https://iep.utm.edu/evil-log/. Earlier studies also tended to focus on the distinction between suffering and evil, as is evident in the titles of older publications, including, inter alia, those of Nicholas La Para, "Suffering, Happiness, Evil," Sophia 4 (1965): 10-16 and George Schlesinger, "The 
If God is all-powerful,

If God is all-knowing,

If God is all-good,

Why is there suffering in the world? ${ }^{4}$

When restated as a set of premises, however, what exactly puts the L and P parts in the logical status of the LPE as a purported contradiction is less obvious: ${ }^{5}$

(1) God is omnipotent.

(2) God is omniscient.

(3) God is perfectly good.

(4) Evil exists.

The LPE as thus formulated seems to include as its conditions of possibility the presumption of theism, a particular concept of God, a certain view of the nature, meaning and reference of religious language and the identification of suffering with evil of various kinds (e.g. metaphysical, natural and moral). Theistic responses to the LPE typically seek to show that the logical status of the coherence-relation between the premises (1) - (4) is not a contradiction. Doing so often involves conceptual clarification or the update/revision of the belief set through supplementary clauses or premises adding the nuance and specificity perceived to dissolve the apparent discrepancies. Atheistic responses seek to argue that the internal relations of the concepts and of the belief set comprised

Problem of Evil and the Problem of Suffering," American Philosophical Quarterly 1 (1964): 244-247. As for relatively recent and representative related research on the problem of evil in general, see the collections of essays in Peter. Van Inwagen, The Problem of Evil (Oxford: Oxford University Press, 2006) and Robert Merrihew Adams and Marilyn McCord Adams, eds., The Problem of Evil (Oxford: Oxford University Press, 1990); and classically John Hick, Evil and the God of Love (Revised Edition; New York: Harper and Row, 1978). Other overlapping loci include the nature of religious language (particularly the question of its meaningfulness amidst suffering), reasoning in religion (in religious epistemology featuring logic), the attribute of divine goodness (as regards its nature and scope as great-making property), and in arguments against the existence of God, in associated conceptions of the divine. Of course, the problem of evil, as a distinctly philosophical-theological problem, only arises as such on the presumption of certain varieties of theism.

4 Beebe, "Logical Problem of Evil," n.p.

5 Alvin Plantinga, God, Freedom, and Evil (New York: Harper and Row, 1974), Eleonore Stump, "Knowledge, Freedom and the Problem of Evil," International Journal for Philosophy of Religion 14 (1983): 49-58; Hasker William, "Suffering, Soul-making, and Salvation," International Philosophical Quarterly 28 (1988): 3-19; Richard Swinburne, "Does Theism Need a Theodicy?" Canadian Journal of Philosophy 18 (1988): 287-312; and idem. "Some Major Strands of Theodicy?" in The Evidential Argument from Evil (ed. Daniel Howard-Snyder; Bloomington: Indiana University Press, 1996), 30-48. 
of said premises remain incoherent nonetheless. From the associated debates, it is clear why the LPE, as its name says, is a logical problem - it is more concerned with coherency in religious thought than with the question of whether the truth-claims of such thinking are propositionally justifiable.

\section{B RESEARCH PROBLEM AND CONTRIBUTION}

Despite the obvious differences between biblical and philosophical modes of discourse, OT scholars still find it helpful to at least clarify why and how this is the case when discussing suffering in conjunction with remarking on how YHWH was assumed to be related thereto in the world of a given text. Nowhere else is there such a variety of related concerns as when the theologies of the Psalter are discussed. This is partly motivated by the theme's prominence in so many of the Psalms themselves and partly because it also happens to be the number one book that religious readers find consolation in during times of personal suffering. One of the less familiar Psalms that is nevertheless in its own way concerned with problems pertaining to conceptual coherence involving YHWH's attributes in relation to suffering is Psalm $89 .{ }^{6} \mathrm{~A}$ gap in the research

6 For some of the related representative mainstream scholarship on Psalm 89, see Gösta Ahlström, Psalm 89: Eine Liturgie aus dem Ritual des leidenden Königs (Lund: Gleerups, 1959); James M. Ward, "The Literary Form and Liturgical Background of Psalm LXXXIX," Vetus Testamentum 11 (1961): 321-339; Richard J. Clifford, "Psalm 89: A Lament over the Davidic Ruler's Continued Failure," Harvard Theological Review 73 (1980): 35-47; Timo Veijola, "Davidverheißung und Staatsvertrag. Beobachtungen zum Einfluss altorientalischer Staatsverträge auf die biblische Sprache am Beispiel von Psalm 89," Zeitschrift für die Alttestamentliche Wissenschaft 95 (1983): 9-31; Dennis Pardee, "The Semantic Parallelism of Psalm 89," in In the Shelter of Elyon: Essays on Ancient Palestinian Life and Literature in Honor of G. W. Ahlström (Journal for the Study of the Old Testament Supplement Series 31; ed. Boyd Barric and J.R. Spencer; Sheffield: Sheffield University Press, 1984); Hans-Joachim Kraus, Psalms 60-150 (Hermeneia; Minneapolis: Fortress Press, 1989); Marvin E. Tate, "Psalms 51-100," Word Biblical Commentary (Vol. 20; Dallas: Word Books, 1991); Michael H. Floyd, "Psalm 89: A Prophetic Complaint about the Fulfillment of an Oracle," Vetus Testamentum 42 (1992): 442-457; Andre Caquot, "Observations sur le psaume 89," Semitica XLI-XLII (1993): 133-158; Pierre Auffret, Merveilles à nos yeux: étude structurelle de vingt psaumes dont celui de 1 Ch 16,8-36 (Berlin: Walter de Gruyter 1995); Jean-Bernard Dumortier, "Un Rituel d'Intronisation: le Ps LXXXIX 2-38," Vetus Testamentum 22 (2000): 176-196; Frank-L. Hossfeld, "Psalm 89," in Psalmen 51-100 (ed. Frank-L Hossfeld and Erich Zenger; Herders Theologischer Kommentar zum Alten Testament. Freiburg, Basel, Wien: Herder Verlag, 2000), Frank-L. Hossfeld, Ps 89 und das vierte Psalmenbuch (Ps 90-106) in "Mein Sohn bist $d u$ " (Ps 2,7), Studien zu den Königspsalmen (ed. Eckart Otto and Erich Zenger; Stuttgart: Verlag Katholisches Bibelwerk, 2002); Hans-Ulrich Steymans, "Deinen Thron habe ich unter den grossen Himmeln festgemacht - Die formgeschichtliche Nähe von Ps 89,4-5.20-38 zu Texten vom neuassyrichen Hof," in "Mein Sohn bist du" (PS 
related to this matter has been identified as constituted by the absence of any study exclusively concerned with comparing the associated variables in Psalm 89 and the LPE (as opposed to other varieties and to theodicy). ${ }^{7}$ In response, the research question to be answered in the discussion to follow is concerned with if and how the reasoning in the religious language of Psalm 89 linking YHWH's divine attributes to suffering involves anything comparable to what we find in the LPE.

The hypothesis of this study predicts that what has already been noted about Psalm 89's contextually sensitive concern with relating divine attributes to suffering in available related research can be fruitfully correlated and contrasted to counterparts in the LPE. Consequently, the objective of this study is to identify and clarify the nature and scope of LPE-related and unrelated reasoning in the religious language of Psalm 89. The method adopted, adapted and applied will be parts of the descriptive tasks of conceptual clarification in analytic philosophy of religion, experimented with in conjunction with comparative-philosophical concerns with problems of commensurability. ${ }^{8}$ Though Psalm 89 is not a Western philosophical text directly or primarily concerned with issues identical to those of the LPE, the assumption of this study

2,7). Studien zu den Königspsalmen (ed. Eckart Otto and Erich Zenger; Stuttgart: Verlag Katholisches Bibelwerk, 2002); John F.D. Creach, "The Mortality of the King in Psalm 89 and Israel's Postexilic Identity," in Constituting the Community, Studies on the Polity of Ancient Israel in Honor of S. Dean McBride Jr. (ed. John T. Strong and Steven S. Tuell; Winona Lake: Eisenbrauns, 2005); Matthew W. Mitchell, "Genre Disputes and Communal Accusatory Laments: Reflections on the Genre of Psalm LXXXIX," Vetus Testamentum 55 (2005): 511-527; Nahum Sarna, "Psalm 89: A Study in Inner Biblical Exegesis," in Biblical and Other Essays (ed. Alexander Altmann, Cambridge: Harvard University Press, 2013); Sophie Ramond, "La voix discordante du troisième livre du Psautier (Psaumes 74, 80, 89)," Biblica 96 (2015): 39-66.

7 See, for example, Erhard S. Gerstenberger, "Theologies in the Book of Psalms," in The Book of Psalms (Leiden: Brill, 2005).

8 See the associated discussion of these issues in Michael Johnson, "Comparative Philosophy," n.p., The Internet Encyclopedia of Philosophy. Cited 16 November 2020. Online: https://iep.utm.edu/composit/. Though comparative philosophy usually works with different "philosophical" traditions as counterparts and though the present study does not claim such a status for Psalm 89, when limited in exegesis to historical dimensions of the descriptive task of clarifying comparative-philosophical discussions, the differences between biblical and philosophical modes of discourse no longer affect said correlations and contrasts. See also Andy C.L. Crouch, "Made in the Image of God: The Creation of the the Commissioning of the King and the Chaoskampf of YHWH," Journal of Ancient Near Eastern Religion 16/1 (2016): 1-21. 
is that related reasoning in its religious language can be elucidated accordingly, on its own terms, even if not in them. ${ }^{9}$

The scope of the discussion will be limited to the identification and clarification of counterpart contents. Its relation to other approaches is one of supplementation rather than that which purports to replace or respond to more traditional concerns in discussions of the theology of suffering in Psalm 89. In terms of outline, after a brief introduction to the Hebrew text of Psalm 89 and its translation annotated with footnotes identifying the relevant variables, LPErelated concepts and coherence relations are clarified before a synthesis of the findings that precedes the conclusion. The originality of the contribution lies in is exclusive focus on the comparative-philosophical foci, on the one hand and the LPE, on the other. The relevance of doing so lies in the specificity obtained from the associated conditions of the possibility of valid paraconsistent reasoning in the religious language of Psalm 89, and in the new and more nuanced account of why things in the world of the text are the way they are, or why they are there at all.

\section{PSALM 89 AND THE LOGICAL PROBLEM OF EVIL (LPE)}

Generally accepted as consisting of three parts, the Psalm begins with praise and between vv. 2-19, the hymnic element dominates in what has further been subdivided into five strophes based on thematic considerations and movements related to spatiality (i.e. an Introduction [vv. 4-5], the divine incomparability and throne [vv. 6-9], the cosmic battle and creation [vv. 10-13], divine acts and consistent favour [14-15], the divine elect [vv. 16-19]). Based on poetic stylistic and formal criteria, the second section is classified as and confined to the "royal oracle" (or similar) in vv. 20-38. In these first two sections, commentators see "reasons" related to the "divine attributes" and "relations" are given as to why YHWH is praiseworthy. A logical problem of sorts is acknowledged as emergent property of the Psalm once the first two parts are juxtaposed with a third and final section, usually given an overhead classification as "complaint" (or similar") [running from vv. 39-52]. It is further sub-divided as a series of "charges" from the collective [vv. 39-46], followed by a prayer for deliverance

9 For alternative conservative viewpoint of Jewish and Christian viewpoints, see respectively, Yoram Hazony, The Philosophy of Hebrew Scripture (Cambridge: Cambridge University Press, 2012) and Dru Johnson, Biblical Philosophy. A Hebraic Approach to the Old and New Testaments (Cambridge: Cambridge University Press, 2021) 
and/or lament of the individual [vv. 47-49] and communal petitions [vv. 50-52]. As part of an inclusion, the Psalm ends with a doxology [v. 53]. ${ }^{10}$

For the purpose of comparing the related conceptual contents and coherence relations between Psalm 89 and the LPE, the general division of the text summarised above is assumed to be sufficient within the literary-critical analyses in which it represents an answer to the questions generated within the theoretical framework of the associated varieties of biblical criticism. However, another complimentary way of subdividing the Psalm would be to use logical criteria whereby conceptually coherent belief sets are distinguished for practical purposes only. By "logical criteria" is meant no more or less than the structures of reasoning in the religious thought supervening on the conceptual configuration of the relationship between YHWH and suffering in the Psalm's own religious language. ${ }^{11}$ They are discernible but inseparable and, as part of a comparative-philosophical perspective, simply represent a different way of looking at the same data, not mutually exclusive from the more traditional ones. Thematically too, the division of belief sets are based on the two clearly opposing states of affairs featuring propositional content of some of YHWH's attributes and relations to suffering in the world of the text.]

10 For the divisions and associated debates in the research, see the helpful summaries in, inter alia, Pieter M. Venter, "Psalm 89 and Daniel 7," Old Testament Essays 17/4 (2004): 678-691.

11 To be sure, some studies focus on in "logical analysis", whether technically or in the context of related languages in linguistics and literary criticism. In fact, they have a long and complicated history from before the advent of biblical criticism. For some varying examples in English, see William Temple, A Logical Analysis of Twentie Select Psalms (London: Felix Kingston, 1605); Arthur Gibson, Biblical Semantic Logic: A Preliminary Analysis (Oxford: Blackwell, 1981); Casper J. Labuschagne, "General Introduction to Logotechnical Analysis," n. p. Cited 3 February 2021. Online: www.labuschagne.nl/aspects.pdf. Yet none of these is directly concerned with a comparative-philosophical perspective on Psalm 89 that has the LPE as counterpart and aims to correlate and contrast with how philosophers of religion discuss reasoning in religious thought. On the latter, see David A. Pailin, Groundwork of Philosophy of Religion (Philadelphia: Epworth Press, 1986), 7. A more recent related trend though also not yet applied to these particular themes in this particular manner and to this particular text is that of "second-order thinking" in the Hebrew Bible and Ancient Near East. See Jaco Gericke, “"My Thoughts Are (not) Your Thoughts': Transposed Secondorder Thinking in the Hebrew Bible," Journal for Semitics 27/1: 16, https://doi.org/10.25159/1013-8471/4217. 
Gericke, “The Logical Problem of Evil,” OTE 34/1 (2021): 300-328

\begin{tabular}{|c|c|c|}
\hline & & 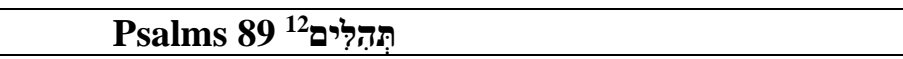 \\
\hline \multirow{12}{*}{ לִּזר } & 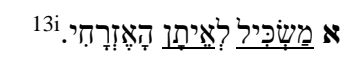 & 1 Maschil $^{\mathrm{ii}}$ of Ethan the Ezrahite. \\
\hline & & $\mathrm{A}^{14}$ \\
\hline & & $\mathrm{Aa}^{* * * 15}$ \\
\hline & 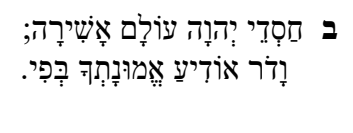 & $\begin{array}{l}2 \text { I will sing of the mercies***m161 of the YHWH for everiiil; } \\
\text { to all generations }{ }^{\text {iv117 }} \text { I'll make known Thy faithfulness }{ }^{* * * 1} \text { in } \\
\text { my mouth. }\end{array}$ \\
\hline & 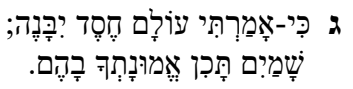 & $\begin{array}{l}3 \text { For I have said: 'For ever }{ }^{\text {iii2 }} \text { is mercy***m2 built; } \\
\text { in the very heavens }{ }^{\text {vh1 }} \text { dost establish Thy faithfulness }{ }^{* * * 22} \text {. }\end{array}$ \\
\hline & & $\mathrm{Ab}^{* * *}$ \\
\hline & 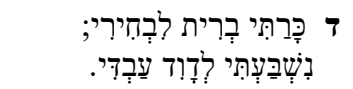 & $\begin{array}{l}4 \text { I have made a covenant with my chosen } \\
\text { I have sworn unto David my servant: }\end{array}$ \\
\hline & 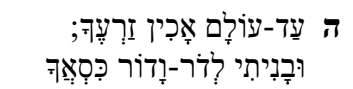 & $\begin{array}{l}5 \text { For ever }{ }^{\text {iii3 }} \text { will I establish thy seed, } \\
\text { and build up thy throne to all generations }{ }^{\text {iv2 }}\end{array}$ \\
\hline & סֶלְה. & Selah \\
\hline & & Ac \\
\hline & 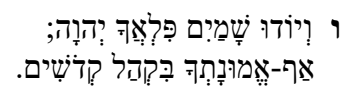 & $\begin{array}{l}6 \text { So shall the heavens }{ }^{\mathrm{vh} 2} \text { praise Thy wonders, YHWH, } \\
\text { Thy faithfulness***f3 also in the assembly of the holy ones. }\end{array}$ \\
\hline & 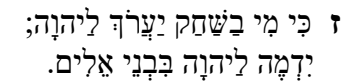 & $\begin{array}{l}7 \text { For who in the skies can be compared unto the YHWH* } \\
\text { who among the sons of might* can be likened unto the YHWH, }\end{array}$ \\
\hline
\end{tabular}

12 All the superscript additions are my own. The Hebrew text and translation were obtained as is from and herewith credited to the website Mechon Mamre. Cited on 17 November 2020. Online: https://www.mechon-mamre.org/. Parts of the English translation have been modified by the present author by replacing the English "Lord" with the divine name in the consonantal Hebrew and by modernising the Old English conjugations of the first-, second- and third-person singular nominative, accusative, genitive and dative reference to the deity. No other adjustments were made.

13 The numbering i, ii, iii denotes logically relevant concepts (part of reasoning in the religious language).

14 A, B Belief sets; a, b Belief subset.

15 For all $*$ superscripts: Divine attributes related to LPE (where $* \geq * * \geq * * *$ ) in the translated terms explicitly used related to: ${ }^{*}$ Concepts related to divine power (hand, power, might, strength); ** Concepts related to divine knowledge (remembrance, foreknowledge, council);

$* * * *$ Concepts related to divine goodness (merciful, faithful, giving, saving, protecting, just, righteous).

16 Superscript alphabetical and idiosyncratic ${ }^{\text {a, b, c..x }}$... abbreviation for concept by first letter of the same word.

17 Superscript numerical (not footnote number): 1, 2, 3 ...consistently reiterated concepts. 


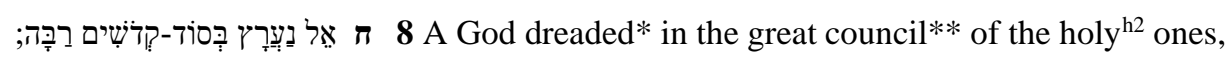

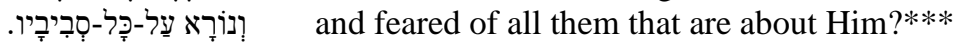

9 YHWH God of hosts, who is like you?

;

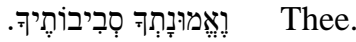

$\operatorname{Ad}^{*}$

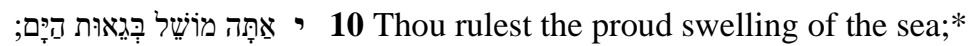
when the waves thereof arise, Thou stillest them.*

11 You crushed Rahab, as one that is slain;*

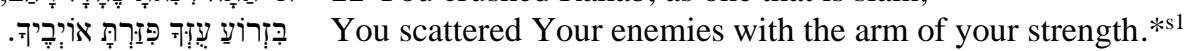

12 Thine are the heavens, ${ }^{\text {vh3 }}$ Yours also the earth;*

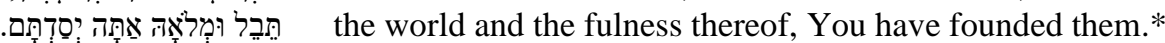

The north and the south, You have created them; Tabor and Hermon rejoice in Your name.

14 Thine is an arm with might; strong is your hand, ${ }^{* * \text { hd1 }}$

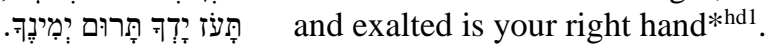

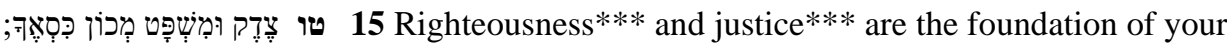

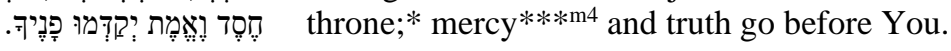

$\mathrm{Ae}^{* * *}$

16 Happy is the people that know the joyful shout;

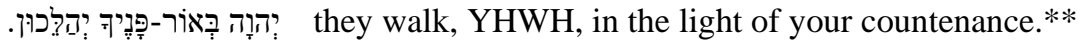

17 In your name do they rejoice all the day; and through your righteousness*** are they exalted.

יח 18 For Thou art the glory of their strength;"**

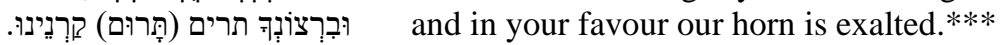

19 For of the YHWH is our shield;*

and the Holy*h3 One of Israel is our king.*

Af

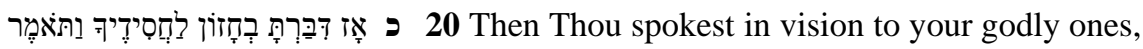

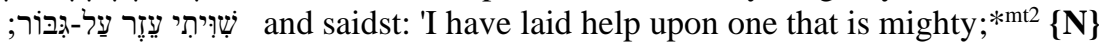

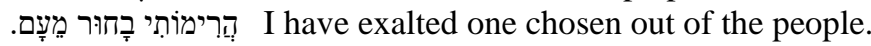

21 I have found David my servant;

With my holy ${ }^{\mathrm{h}}$ oil have I anointed him;

22 With whom my hand*hd3 shall be established;

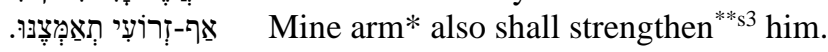

23 The enemy shall not exact from him;

nor the son of wickedness afflict him. \#\#\#18MO

כד 24 And I will beat to pieces his adversaries before him,

18 Suffering or here in the counterpart sense of evil in the world of the text (suffering) (where \# $\geq \# \# \geq \# \#$ ) (dual causality assumed) and \# Me Metaphysical evil; \#\# Ne Natural evil; \#\#\# Mo Moral evil. 


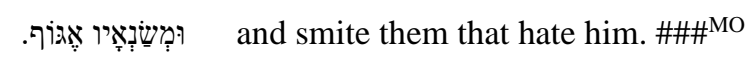

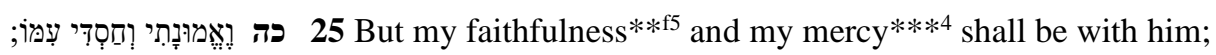

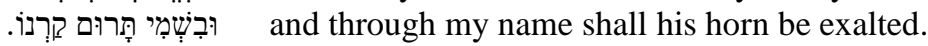

26 I will set his hand**hd4 also on the sea,

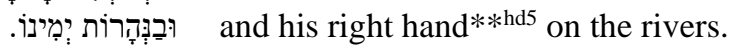

27 He shall call unto Me:

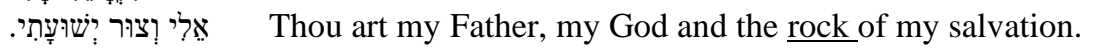

28 I also will appoint him first-born,

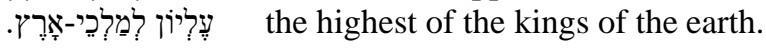

29 For ever ${ }^{\text {iii4 }}$ will I keep for him my mercy***m5,

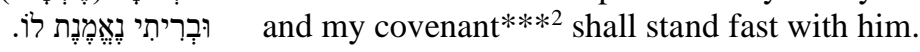

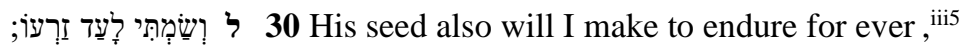

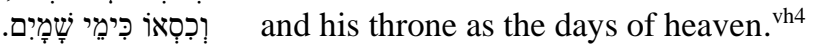

$\mathrm{Ag}$

31 If his children forsake my law,

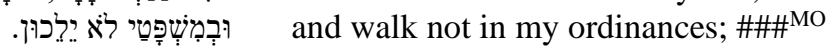

32 If they profane my statutes,

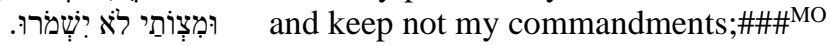

33 Then will I visit their transgression with the rod,

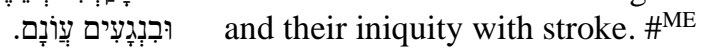

$\mathrm{Ah}$

34 But my mercy**m6 will I not break off from him,

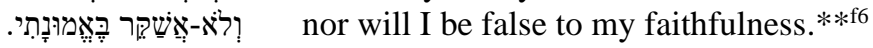

35 My covenant***3 will I not profane,

nor alter that which is gone out of my lips.

36 Once have I sworn by my holiness:

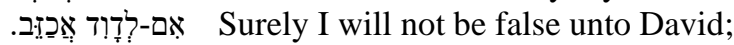

37 His seed shall endure for ever, ${ }^{\text {iii6 }}$

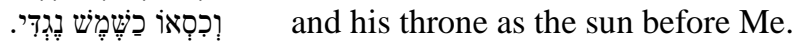

38 It shall be established for ever ${ }^{\text {iii7 }}$ as the moon;

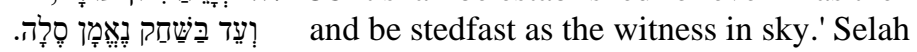

\section{B}

$\mathrm{Ba}$

39 But You have cast off and rejected,

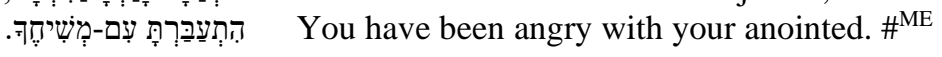

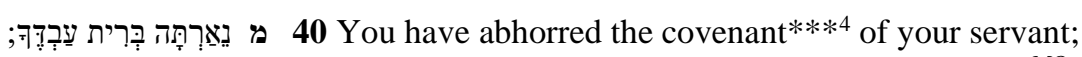

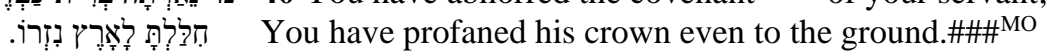

41 You have broken down all his fences; You have brought his Strongholds to ruin.\#\# ${ }^{\mathrm{NE}}$ ?

42 All that pass by the way spoil him;

Ge is become a taunt to his neighbours. \#\#\#O 


\begin{tabular}{|c|c|}
\hline 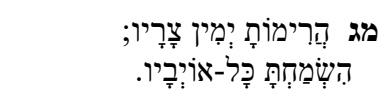 & $\begin{array}{l}\mathbf{4 3} \text { You have exalted the right **hd5 of his adversaries; } \\
\text { You have made all his enemies to rejoice.\#\#\#MO }\end{array}$ \\
\hline 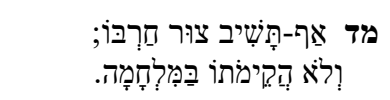 & $\begin{array}{l}44 \text { Yea, you turn back the edge of his sword, } \\
\text { and hast not made him to stand in the battle.\# } \#^{\mathrm{NE} / \mathrm{MO} \text { ? }}\end{array}$ \\
\hline 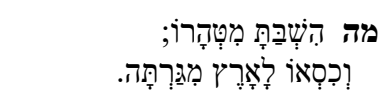 & $\begin{array}{l}45 \text { You have made his brightness to cease, } \\
\text { and cast his throne down to the ground. } \#^{\mathrm{ME}}\end{array}$ \\
\hline \multirow[t]{2}{*}{ 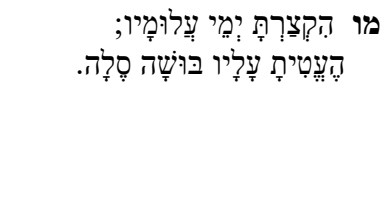 } & $\begin{array}{l}46 \text { The days of his youth you have shortened; } \\
\text { You have covered him with shame. } \\
\text { Selah } \#^{\mathrm{ME}}\end{array}$ \\
\hline & $\mathrm{Bb}$ \\
\hline 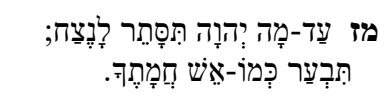 & $\begin{array}{l}47 \text { How long, YHWH, will you hide yourself for ever }{ }^{\text {iiir? }} \text { ? } \\
\text { How long shall your wrath burn like fire? }\end{array}$ \\
\hline 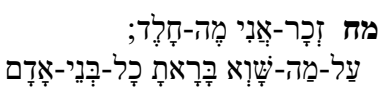 & $\begin{array}{l}48 \text { O remember** how short my time is; for what vanity hast } \\
\text { You have created all the children of men!\# } \#^{\mathrm{ME}}\end{array}$ \\
\hline \multirow[t]{2}{*}{ 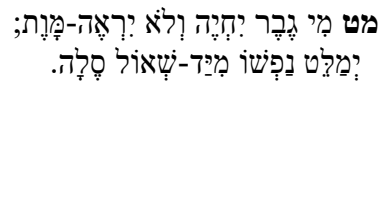 } & $\begin{array}{l}49 \text { What man is he that lives and shall not see death, } \\
\text { that shall deliver his soul from the power of the grave?* } \#^{\mathrm{ME}} \\
\text { Selah }\end{array}$ \\
\hline & $\mathrm{Bc}$ \\
\hline 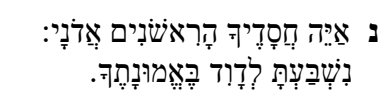 & $\begin{array}{l}\text { 50 Where are your former mercies***m7 } \text {, o Lord } \\
\text { which you swore to David in your faithfulness? } * * * 77 \#^{\mathrm{ME}}\end{array}$ \\
\hline 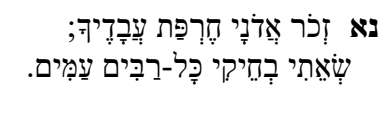 & $\begin{array}{l}\text { 51 Remember**o Lord, the taunt of your servants; } \\
\text { how I do bear in my bosom [the taunt of] so many peoples; } \\
\text { \#\#\#MO }\end{array}$ \\
\hline \multirow[t]{2}{*}{ 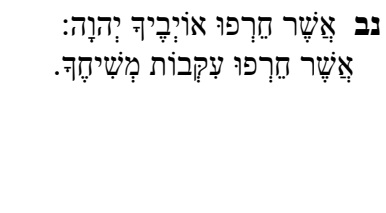 } & $\begin{array}{l}52 \text { Wherewith your enemies have taunted, YHWH, } \\
\text { wherewith they have taunted the footsteps of your anointed: } \\
\# \# \#^{\mathrm{MO}}\end{array}$ \\
\hline & $\mathrm{Ai}$ \\
\hline 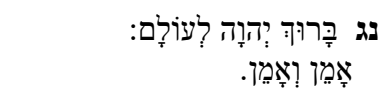 & $\begin{array}{l}\mathbf{5 3} \text { Blessed be the YHWH for evermore. }{ }^{\text {iii }} \\
\text { Amen, and Amen. }\{\mathbf{P}\}\end{array}$ \\
\hline
\end{tabular}

\section{LPE-related conceptions of divine attributes in Psalm 89}

As regards the specific divine attributes in the LPE, when compared with related ones about YHWH in Psalm 89, it is clear that whatever counterparts are present for correlation and contrast, one cannot simply restate the problem for the psalmist by substituting the divine name in the following manner:

1. If YHWH is all-powerful,

2. If $Y H W H$ is all-knowing,

3. If YHWH is all-good,

4. Why is there suffering in the world? 
This is clearly comparative-philosophically (exegetically) suspect, not only because it begs the question of whether YHWH was thus attributed in the world of the text. Even if that was the case, it cannot simply be assumed that these attributes were understood in the same senses they came to be in later philosophical theology. ${ }^{19}$ In fact, one may also ask whether YHWH's being powerful, knowing and good - LPE related divine attributes ${ }^{20}$ - were in fact those the Psalmist is actually concerned with when describing the divine relation to suffering. Moreover, is the suffering referred to in Psalm 89 of the general and universal kind presented in the LPE? Based on what can be discerned from what is implied in historically-conscious (critical) readings of the Psalm, the answer is negative on all counts.

First, the following may be noted with reference to LPE-related notions of divine power represented in various ways in Psalm 89. ${ }^{21}$ Comparing this with the wording in the LPE and restating it in mere equivalent terms would be considered contextually suspect. Though YHWH's power is presented as unrivalled, it is not considered logically unlimited. In fact, in contrast to the usual notions of omnipotence in later philosophical theology, great but relative divine power in relation to suffering is a condition of possibility for the meaningfulness of praising YHWH for being victorious in the battle against the monster of chaos and the enemies of the people. ${ }^{22}$ To be sure, conceptually-historically, the idea of YHWH's power has progressed to the extent that losing a battle is inconceivable. Nonetheless, the residual mythological elements in the poem's

19 A much related and very relevant comparative-philosophical discussion of these divine attributes in the Hebrew Bible albeit with reference to metaphorical religious language in the prophetic texts and from the side of philosophical theology deserving of mention is, among many, Keith Ward, Concepts of God: Images of the Divine in the Five Religious Traditions (Oxford: Oneworld Publications, 1998), 111-133. In philosophy of religion, the Hebrew Bible features "inexact metaphysics," as noted in Don Cupitt, Taking Leave of God (London: SCM Press, 1981), 85. As such, within ancient philosophical theology, it would be classified anachronistically as part of the poetical or fabulous rather than philosophical theology; see Don Cupitt, After God: The Future of Religion (London: SCM Press, 1997), 113.

20 On the philosophical-theological background and comparative-philosophical interests of OT scholars' references to YHWH's divine "attributes" or related terms, for example, among others, "characteristics," "qualities," "properties," "marks," see Jaco Gericke, A Philosophical Theology of the Old Testament: A Historical, Experimental, Comparative and Analytic Perspective (London: Taylor and Francis, 2020), chapters $2-3$.

21 For the applicable more explicit in-text referencing, see the applicable superscript $*$ above.

22 Cf. Fretheim, The Suffering of God, 11. Of course, this implies the presence of divine suffering as well, in the shame that the Psalmist implies YHWH is suffering and, of course, the suffering of someone in anger in response to a cause sufficient to elicit it. 
archaising religious language and its recourse to the metaphor of the divine king and warrior do not yet allow the reasoning therein to operate without celebrating divine agency with reference to the supervening divine relations.

With reference to (2) - YHWH is all-knowing - it is clear that when compared, Psalm 89 features less explicit concern with LPE-related counterparts for the attribute of divine knowledge than the latter. ${ }^{23}$ In ways implicit throughout, though in LPE the role of the premise of divine omniscience is paramount in the context of relations to suffering, the nearest associated references thereto in the Psalm are those implicit in the conceptual role of the divine council. ${ }^{24}$ Whereas also in the LPE, it seems difficult to reconcile divine knowledge of all the suffering with its existence, in Psalm 89, it is implied that divine forgetfulness is a possible condition for the meaning and reference of the religious language in the Psalm and for the Psalmist's plea to YHWH to remember. As elsewhere in the OT, however, in Psalm 89, it is not so much assumed that YHWH cannot know everything. Rather, as usual, the metaphors for the divine roles such as king, master, warrior, father and judge in turn require the mediation of knowledge via intermediary channels, for example, messengers, communication, testing, etcetera.

With reference to (3) - YHWH is all-good - again, a number of LPErelated yet different terms and conditions in the Psalm can be identified. ${ }^{25}$ Here, the Psalm also assumes some limits to divine goodness in relations noted above and not reducible to the constraints usually associated with an omnibenevolent deity as in responses to the LPE (which will be discussed later). It is not that YHWH was viewed as an evil god. Rather, the Psalmist's religious language allows for dystheistic elements in its conception of the divine in establishing a more direct dual causal relation between the deity and seemingly senseless human suffering. What makes this possible is the reasoning in the religious thought warranted by the role requirements of being an incomparably powerful divine king, master, warrior, father and judge. These require divine roles in suffering that is alien to modern readers, assuming a concept of divine goodness of the kind more typical of the perfect being theology usually associated with the concept of God implicit in the LPE. It is clear also that in Psalm 89, far more emphasis is placed on terms and conditions related to divine goodness than any other attribute. This is evident in the number of references to divine mercy and faithfulness in the Psalm. The quantitative difference in emphasis implies an

23 For the applicable more explicit in-text referencing, see the applicable superscript ** above.

24 Fretheim, The Suffering of God, Chapter 4.

25 For the applicable more explicit in-text referencing, see the applicable superscript ** above. 
initial privileging of propositional content related to varieties of divine goodness over those of divine power (second) and knowledge (third).

Moving on from the attributes in (1) - (3) to the problem of the existence of "evil" in (4) - Why is there suffering in the world? - some of the textual contents may be noted as LPE-related. ${ }^{26}$ Clearly, the kind of suffering that is of interest to the Psalmist is hardly as general as the evil alluded to in the LPE. That being granted, what was later distinguished as different types of evils are all nevertheless included in the conceptual background of suffering in Psalm 89. For example, one can discern the presence of so-called metaphysical evil ${ }^{27}$ (especially in the lament's incoherent divine causal relations, contingency, imperfection, injustice). One example of this can be found in the context of the negative reference to the loss of personal identity, the ephemerality of human existence and the finality of death in vv. 48-49. The so-called natural evil ${ }^{28}$ is taken for granted as part of life, even though in Psalm 89, it appears contextually anomalous, that is, not warranted on covenantal terms and conditions. Examples are the implied concern with disease, disasters and assorted forms of suffering associated with the absence of covenantal blessings (as though the curses are actualised). Lastly, localised atypical experiences of so-called moral evil, ${ }^{29}$ that is, immoral actions by human agents (enemies of YHWH) causing suffering, are highlighted in the Psalm. These are most prominent in the second part, from v. 39 onwards. Whether taking the form of violence or hurtful words, this is where the heart of the Psalmist's problem with suffering appears to lie. Why this problem is also of a "logical" kind will be demonstrated next. However, before doing so, a few additional remarks on the metaphysical assumptions in the world of the text and on divine attributes and relations to suffering are needed.

To be sure, in Psalm 89, things are not as clear-cut as as implied by the discussion in this section thus far. All associated content in the Psalm presupposes divine goodness, power and knowledge so that what was noted above applies more to explicit content. Moreover, as in the LPE, in Psalm 89 the relevant divine attributes can be distinguished but not separated on the ontological level and with reference to the implicit mereology or part-whole relations. This is clear despite the fuzzy concepts in the metaphorical religious language that is able to operate without high levels of specificity as regards the

26 For the applicable more explicit in-text referencing, see the applicable superscript \# and extensions above.

27 For the applicable more explicit in-text referencing, see the applicable superscript \# above.

28 For the applicable more explicit in-text referencing, see the applicable superscript \#\# above.

29 For the applicable more explicit in-text referencing, see the applicable superscript \#\#\# above. 
extensions and intensions of the associated Hebrew terms. Prototypical covenantal confessional qualities of YHWH and the proxy-typical contexts of suffering combine in the analogical (metaphorical) religious language of the Psalm in ways that are not ideal for analytic approaches to the LPE's requirement for univocal and concise modes of expression.

Unlike in the LPE, in Psalm 89, an answer to the question of why suffering exists is actually given, that is, it is due to YHWH's anger. The latter is assumed to count as divine motivation in the actualisation of what are perceived to be unjust divine agency and its absence or divine hiddenness. The cause of the divine wrath itself is not mentioned and certain possible theodicies are ruled out as sufficient reason. Herein lies the conceptual conundrum for the Psalmist. Given whom YHWH is and what YHWH has revealed, and in light of the terms and conditions of the covenant, the suffering that exists is a problem. Though proximate and other causes for the suffering are identified (YHWH's actions, disposition and absence, the enemies), the reasoning in religious thought featuring the divine attributes and relations to suffering in the world of the text cannot make the associated propositional attitude reports (beliefs) cohere. To reveal how this is implied to be a logical problem, a further analysis of the logical structure of the beliefs about YHWH's relation to suffering in Psalm 89 is required.

\section{LPE-related coherence-relations and reasoning in Psalm 89's religious language}

Formally and structurally, the reduction of Psalm 89's problem with suffering to LPE-type premises are also exegetically problematic. Even if sufficient semantic overlap is created, pragmatically, something is lost in the comparativephilosophical restatement. As will be demonstrated below, reducing the complex prayer consisting of various poetic forms to an LPE set of premises actually deprives the Psalmist's case from its required thoroughness and rhetorical efficiency. The latter cannot occur in the LPE format, for the writer's concerns with suffering demanded second-order reasoning in religious language, thus, the ultimate objective lay elsewhere. To see why and how this is so, it is time to compare the coherence-relations in the counterpart contexts.

Below are the auto-logical components of the propositional attitude reports implicit in Psalm 89 and represented as two belief sets ${ }^{30}$ about how YHWH's divine attributes were assumed to relate to suffering:

30 On the role of belief sets in the context of belief revision logic, see Sven Ove Hansson, "Logic of Belief Revision," n.p. in The Stanford Encyclopedia of Philosophy (ed. Edward N. Zalta; Winter 2017 Edition). Cited 10 November 2020. Online: https://plato.stanford.edu/archives/win2017/entries/logic-belief-revision/. 
A. The set of beliefs in vv. 1-38 (52) wherein one finds the following states of affairs which the Psalmist purports meet all the criteria for knowledge in the sense of justified true belief as they are revealed and verified and guaranteed by YHWH himself:

a. YHWH's eternal mercy and faithfulness (89:2-3);

b. YHWH's eternal covenant with the anointed elect (89:4-5);

c. YHWH's divine incomparability in the divine council (89:69);

d. YHWH's divine power in taking possession of the world following his primordial victory as divine warrior and the creator of the regions named (89:10-15);

e. YHWH's divine relations to and election of his people who qua YHWH's people and in light of a-b are justified in being happy for divine power and protection (89:16-19);

f. YHWH's divine revelation of assurance of the relation to and through the king and his preservation as divine son and representative endowed with the associated divine attributes of power and justice in the face of opposition eternally assured as conferred (89:20-30);

g. YHWH's justice in divine judgment of contravention of covenantal terms and conditions as only an exception of divine favour or cause for non-normal types of suffering among the people $(89: 31-33)$;

h. YHWH's divine revelation and testimony give assurance that irrespective of $\mathrm{f}$ and in light of a-e divine faithfulness and mercy in the upholding of the divine covenantal relations will last forever (89:34-38);

i. YHWH's worship in conclusion, notwithstanding what was said and without any solution to the theo-logical problem (89:53).

B. The set of beliefs in 39-51 featuring the following paraconsistent states of affairs:

a. YHWH's divine anger expressed through the divine rejection of the anointed for no sufficient reason (e.g. in Ae), the destruction of what was repeatedly affirmed, promised and otherwise able to be the eternal covenant, YHWH's unfaithfulness and lack of mercy in the context of causal relations in the suffering and shame of his kingdom, his people at the hands of their enemies, destroying both the rule of the elect and the eternal seed of the anointed himself (89:39-46); 
b. YHWH's hiddenness and anger without cause, for a potentially indefinite time along with YHWH's implied forgetfulness of the individual's mortality (89:47-49);

c. YHWH's mercies and faithfulness being absent and withdrawn, despite the promises implying the impossibility of the current divine relations with the anointed and YHWH's forgetfulness and inaction amidst the suffering of the people as a result of His and their enemies' anger and in ways outside the scope of covenantal terms and conditions (89:50-52).

The subsets Aa-Ah before B and Ai following B are connected with the latter providing the inclusion and ending according to protocol rather than on a high note wherein the anomalies that have arisen in the states of affairs that obtain in the world of the text in $\mathrm{Ba}-\mathrm{Bc}$ have been resolved. The reasoning in the religious language in A and B are connected by way of B's negation of beliefs also involving but not limited to LPE-related divine attributes in the context of various forms of evil and suffering. The logical status of intended partial contradiction is therewith instantiated as emergent property in the informal logical coherence-relations across the various literary forms adopted within the overall case being made in prayer. ${ }^{31}$ In other words, it would appear that the Psalmist used religious language in paraconsistent ways to construct deliberately and purposefully an incoherently related mereology. The logical status of the religious language was desired to be contradictory, not because the speaker likes or accepts the incoherencies in the propositional attitude report. Rather, it is just that there would be no cause for or validity in constructing a complaint in the Psalm unless one assumes that the Psalmist both valued logical consistency and reluctantly entertained the possibility of the need for belief revision. The latter with regard to the exemplification of YHWH's relevant attributes and/or relation to the forms of suffering that the Psalmist has in view.

In other words, the reasoning implicit in the explicit religious language of Psalm 89 includes but is not limited to what can be described as an implicit paraconsistent coherence relation between belief sets A and B. Of course, only some beliefs about YHWH's divine attributes in A eventually become incoherently related to those in B. Moreover, the negation of concepts, premises or conditional propositional of beliefs about YHWH's relation to suffering in B that is so related is constructed as doing so in a logically precise manner. The intentionally paraconsistent coherence relation between beliefs in Psalm 89 becomes clear when, starting with $\mathrm{B}$, one notes only those conceptual contents

31 Of course, logic crosses over into epistemology here. All assumptions related to logical relations also presuppose the presence of epistemological assumptions. As noted by James Murphy, "Coherentism in epistemology," n.p. The Internet Encyclopedia of Philosophy. Cited 20 December 2020. Online: https://iep.utm.edu/coherent/\#SH3b. 
actually contradicted across different subsections of A vs. B. This is evidenced in the following examples:

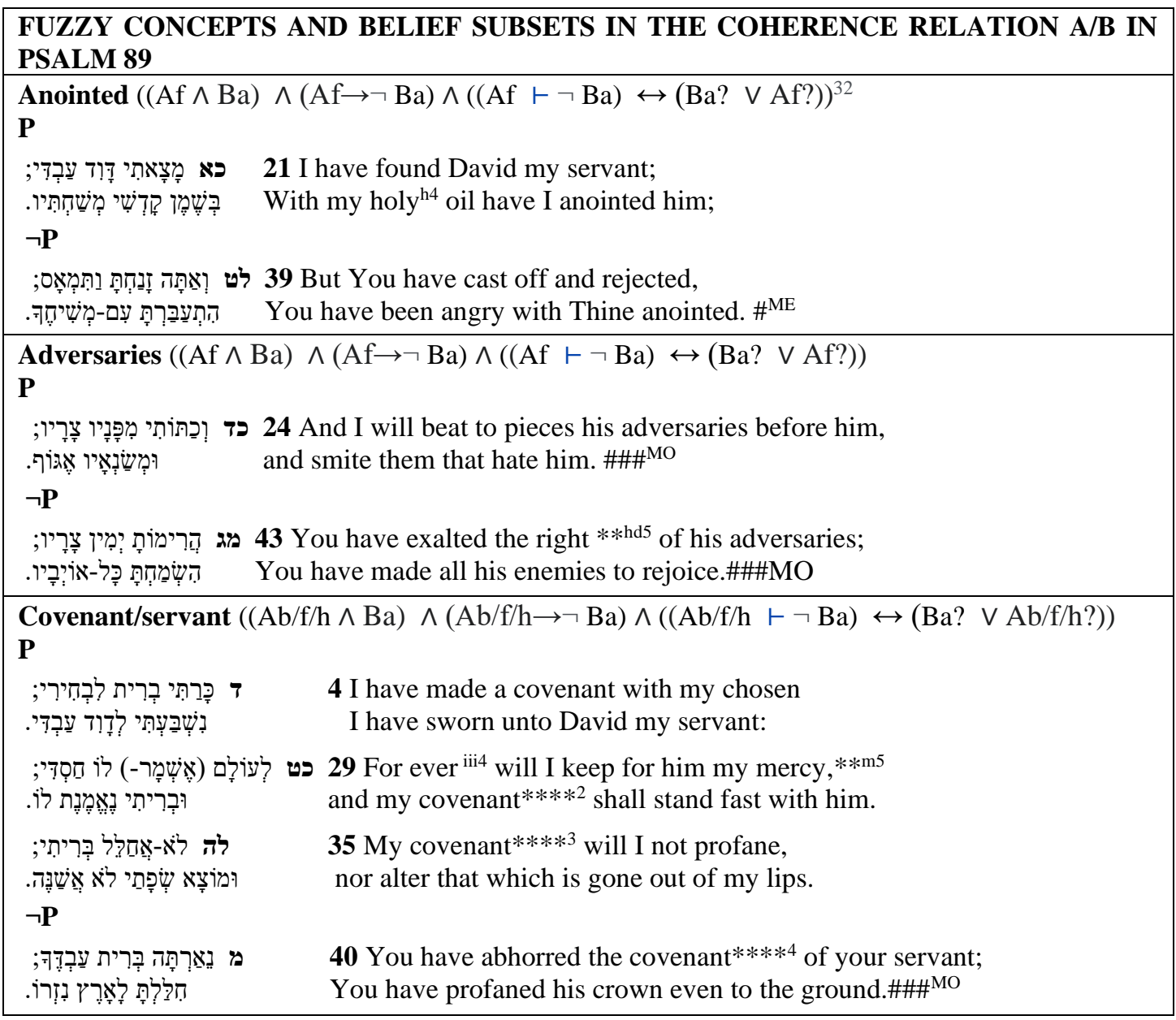

$32((\mathrm{Af} \wedge \mathrm{Ba}) \wedge(\mathrm{Af} \rightarrow \neg \mathrm{Ba}) \wedge((\mathrm{Af}\llcorner\neg \mathrm{Ba}) \leftrightarrow(\mathrm{Ba}$ ? $\vee$ Af? $)$ features the standard logical operators for conjunction $\wedge$ "and," material implication $\rightarrow$ "if, then," negation $\neg$ "not", entailment $上$ "follows from" and $\leftrightarrow$ biconditional "if and only if" and disjunction $\vee$ "or." The brackets ( ) are simply to keep clauses together and distinguish the different ways the logical form of the Psalmist's problem could be formalised, if one wanted to, even though the logic is too vague and fuzzy for these technical notations and operators to be useful in purely abstract forms. Thus, with reference to the "anointed, the sentence reads that the reference to the anointment in belief subsets Af and $\mathrm{Ba}$ are assumed to be true and that if Af is true then Ba is not and if Af obtains then Ba does not follow or is not entailed and all this if and only if the Psalmist were questioning how both could be the case. With reference to $\mathrm{P}$ as propositional contents for the state of affairs obtaining in the world of the text and its negation, the same applies with reference to intended paraconsistency. The question of whether it is an actual contradiction should be distinguished from the Psalmist's rhetorical objective. 


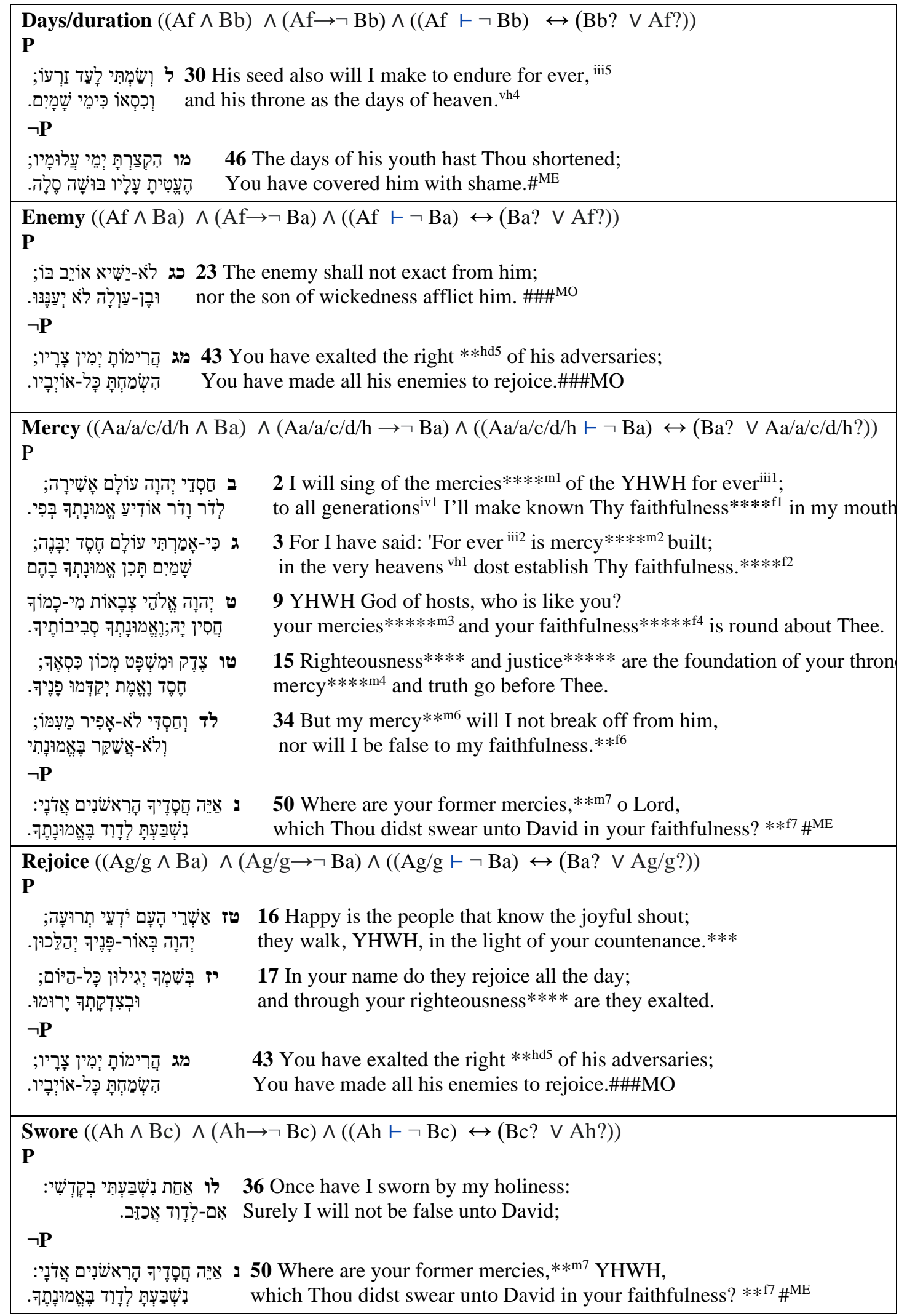




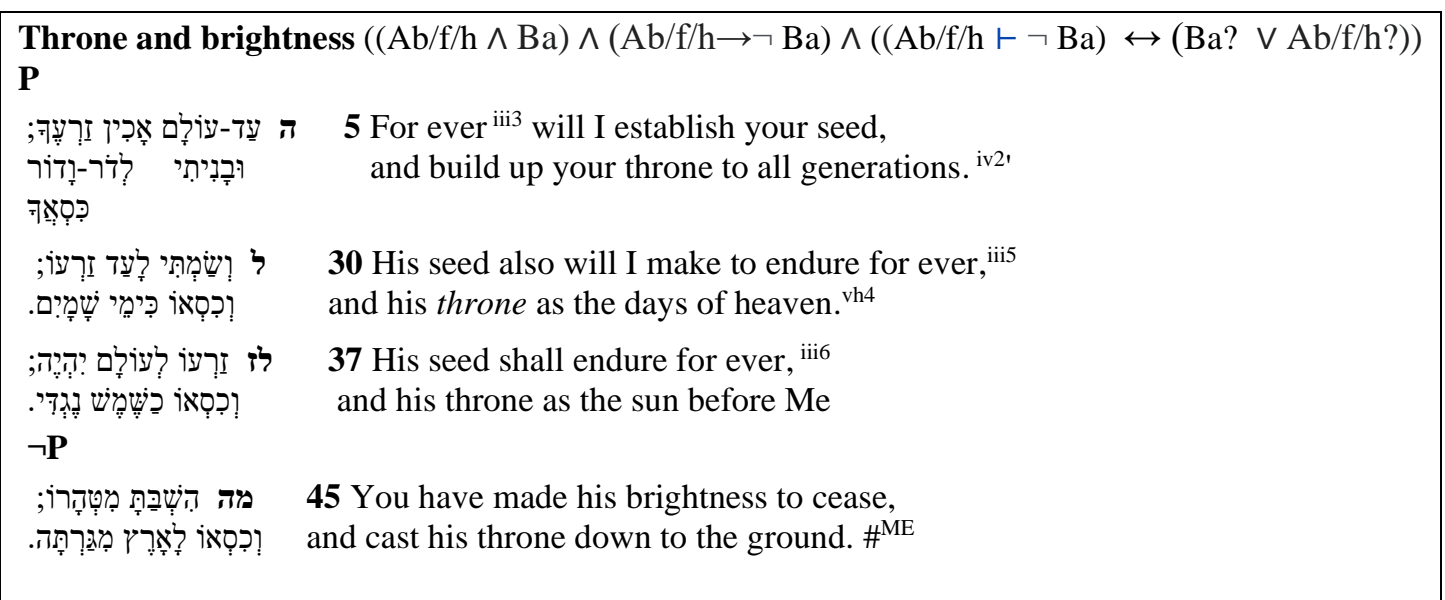

From the above, it is readily apparent that certain concepts are clearly privileged by the writer for constructing the discrepancies in the coherency relations. Evident also is how the paraconsistent beliefs represented by the conjunction of belief sets A and B in the Psalm as a whole were orientated to match only associated divine attributes and relations to suffering as supervened by the actual state of affairs obtaining in the world of the text in B. This allowed for the iteration of conceptual content actually perceived to be problematic and in need of negation in order for the logical status to emerge in the coherence relation between $\mathrm{A}$ and $\mathrm{B}$. The intentional nature of the discrepancies in the coherence-relations identified as $\mathrm{P}$ and $\neg \mathrm{P}$ above imply the presence of a logical problem of evil of sorts, in the Psalm's own highly specific and nuanced terms and conditions only. The coherency relation thus established by beliefs in B whereby those in A are negated, moreover, are obviously not limited to a concern with divine attributes of the LPE kind.

\section{COMPARATIVE-PHILOSOPHCAL SYNTHESIS}

In this penultimate part of the discussion, as hinted at in the introduction in the section on method, it is time to consider some of the ways in which the present reading of the Psalm has identified elements related to the comparativephilosophical problems associated with the idea of "incommensurability." 33

With reference to the relevant divine attributes and types of suffering or evil, the comparative-philosophical correlation and contrast are already complicated by the fact that in the LPE, the logical problem cannot be divorced from the kind of philosophical monotheism wherein perfect being theology is conceptualised through maximally great states of affairs in divine great-making properties. Therefore, with reference to Psalm 89 , how is one to restate the

33 On the idea of incommensurability, see David Wong, "Three Kinds of Incommensurability," in Relativism: Interpretation and Confrontation (ed. Michael Krausz; Notre Dame: Notre Dame University Press, 1989). 
logical nature of the problem in the context of the divine council making Psalm 89 not strictly monotheistic in the metaphysical sense of the term in classical theism? Second and complicating the first point, Psalm 89 nevertheless displays monotheistic tendencies, as all the divine entities are assumed to be ontologically dependent on YHWH for their existence and nowhere identified as playing any meaningful part in the dual causal relation in the actualisation of suffering. For all theoretical purposes then, comparing counterpart variables to the concept of God with reference to the nature of theism in the LPE is complicated by the need for additional nuance and specificity regarding YHWH's numerical identity within the broader multiplex typology of divinity. ${ }^{34}$

In Psalm 89, there is also no concept of divine perfection simpliciter. Instead, the closest counterpart is found in the property of divine incomparability as instantiated and exemplified in the ways described in vv. 5-9. The incomparability motif is no abstraction, however, and the associated divine attributes and relations to suffering obtain only in analogical religious language, which is supervened on and contextualised by the metaphors of the divine king, master, warrior, father, judge. This conjunction of fuzzy sets features a selection of highly nuanced role-relative accidental divine attributes, as may be validly inferred from the target domains of these metaphors, runs the risk of generating paraconsistent propositional content, so much the more when an anomaly arises after suffering is introduced as emergent property in the events described by the state of affairs obtained in the world of the text. For what makes one great in one divine role is not so in another. What makes and is required of a great king can at times lead to a conflict of interest when also acting in the role of a great father, warrior, master, judge and so on. In such a multi-metaphorical conceptualisation of the divine, a conceptual conflict of interest can and has arisen in Psalm 89 that is not resolved by an appeal to the nature of its religious language.

Differences between concepts of God in the LPE and in Psalm 89 also impinge on the theological status of the deity. Ontologically, the existence of suffering in the world of the text is no more considered the basis for an atheological denial of the deity's existence than it would be when an otherwise good king or father has had a change of heart leading to suffering. Axiologically as well, there is a difference between Psalm 89 and part of the LPE in that the former does not operate with the theological assumption that a god is to be

34 On associated historical and methodological issues in a comparative-religious context, see the highly respected contributions by Mark S. Smith, God in Translation: Deities in Cross-Cultural Discourse in the Biblical World. Forschungen zum Alten Testament series I, volume 57 (Tübingen: Mohr Siebeck, 2008) and idem., "Monotheism and the Redefinition of Divinity in Ancient Israel," in The Wiley Blackwell Companion to Ancient Israel (ed. Susan. Niditch; Oxford: WileyBlackwell, 2015). 
worshipped only if omnibenevolent. The other side of the coin is also a difference between Psalm 89 and the LPE in terms of conceptualisation of divine causality in relation to human freewill. These are religious-historically and socio-culturally so different that the so-called freewill defence, resorted to often in popular responses to the LPE, would not be applicable to the Psalmist-not because the writer is a determinist or denies the moral importance of some human freedom of the will. Rather, the relevant instantiation thereof is not applicable as the suffering in the world of the text is not assumed to be the consequence of errant human volition, divine anger and dual causality notwithstanding.

Another difference is that while what is required from a theistic response to the LPE is only showing that no actual contradiction is present, this is often done in conjunction with the need to present a theodicy. In Psalm 89, nothing could be further from the truth in terms of motivating factors for the speakernot that the writer of Psalm 89 sought to present an anthropodicy either. From the discussion above, in terms of theo-logical form, the Psalm can be classified as an atheodicy, that is, an attempted case against divine justice or a charging of the deity with injustice. To read Psalm 89 as such, as though representing both the case of the defence and the prosecution in a court case, ${ }^{35}$ not only makes sense of why there was the need to present first a belief set featuring what YHWH has revealed about the divine attributes in relation to suffering, only to follow this up with a complaint about the contrary. It would also explain the rhetorical motive for the reiterations and carefully constructed emphases on certain idiosyncratic elements within what had to end up with paraconsistency in the coherence relation as condition of possibility for the validity of the claim that YHWH has caused unwarranted suffering. This in turn explains why the problem

35 For samples of the associated OT theological conceptual history, see Walter Brueggemann, Theology of the Old Testament: Testimony, Dispute, Advocacy (Minneapolis: Fortress Press, 1997), passim. In a way, the logic of identity in the religious language of divine power in Psalm 89 is dialectical in a way that is similar to Hegel's later (Master-Slave) construction as struggle for recognition and in Nietzsche as part of a moral typology. More familiar to Psalms scholars would be Martin Buber's I-Thou personalism which was not only influenced by Hegel's dialectics but also influenced OT theologians who adopted it in more discrete forms in the classical period up to Brueggemann. This used to be the preferred comparative-philosophical way to conceive of divine relations in the context of divine power in prayer, of course, in the heyday of biblical theology and this is not daring to credit the source's philosophical (as opposed to ethical or theological) insights. It was easier to do where so-called Continental traditions in philosophy overlapped with sociology and history than it was with the formalism of analytic philosophy of religion or philosophical theology. Later relevant receptions not yet sufficiently represented in research on the Psalms would then be those of Lacan's logic of the Master and Foucault's idea of power-as-relations, both of potential relevance for comparative-philosophical correlation and contrast in future research on divine power in the Psalms. 
of suffering in relation to the divine attributes had to be a logical one, in the sense of reasoning in the religious language leading into opposite conclusions in $\mathrm{A}$ and B.

In other words, the more the beliefs in B do not follow from A, the greater the logical problem of evil or suffering and, paradoxically, the stronger the atheodicy. This is yet another reason why the logical form of the problem of suffering in Psalm 89 is not reducible to an LPE set of premises or series of conditional sentences without losing key rhetorical elements. That being said, if one had to try for the sake of argument and experiment with all qualifications thus far considered applicable, it is possible for the reasoning in the religious language required for the atheodicy featuring beliefs about YHWH and suffering to be hypothetically abstracted and restated in the following conditional form:

(1) If YHWH's is assumed to be the most powerful and mighty god;

(2) If YHWH remembers and is without comparison in the council of the gods;

(3) If YHWH is good in terms of sworn eternal devotion, loving-kindness and loyalty to the covenant to David;

(4) Why is there suffering because of YHWH's angry abrogation of the covenant expressed through enemy evil?

Statements (1) through (4) jointly imply that if YHWH has revealed himself as the Psalmist asserts and is the kind of God thus revealed, there would not be suffering of the kind that is associated with the state of affairs where there is no longer a covenant in place. Without claiming that the reasoning in the religious language of the Psalm as a whole can be reduced to these LPE related conditional sentences in 1-3 and the question in 4, they represent a closer way of comparative-philosophically restating what the supervening concepts, concerns and questions in the various parts of the Psalmist's problem on its own terms, even if not in them. The same perspective, qua logical problem of evil as condition of possibility for the complaint, can be summarised to include the following premises:

(1) YHWH is the most powerful among the gods.

(2) YHWH is without comparison in the council of the gods.

(3) YHWH is good in terms loving-kindness and loyal to the covenant with David.

(4) Suffering of a non-covenantal kind exists.

In the world of the text, all of them are believed to be true at the same time; yet because of the assumption that not all of them could or should be true, the writer of Psalm 89 has an atheodicy to present by way of their conjunction as one paraconsistent belief set $\mathrm{AB}$. On the level of the coherence relation then, the question of commensurability arises given different modes of discourse represented by and in Psalm 89 vis-à-vis the LPE, whether in conditional or 
premise form. The diversely formulated presented case of atheodicy in a poetic song/prayer versus a logical argument by default differs on what counts as evidence and grounds for decidability. In relation to philosophy of religion, contrary to the LPE then, the logical problem of evil in Psalm 89 is not how to reconcile a perfect deity with evil in the world but how to show that what YHWH being YHWH has said and done did not square with what YHWH himself is believed to have done in and to the world of the text.

In making the case against YHWH's injustice in poetry and prayer, the Psalmist's logical problem with suffering obtains an added dimension of complexity because of the pragmatics supervening on its construction. It was indeed a most difficult task the poet had. The logical dilemma is clearly covenantally contextualised and constrained by various supervening metaphors and religious-historical and biblical-theological specific presuppositions, problems and perspectives. The religious language and reasoning operative in making the case for divine injustice in relation to suffering had to be painstakingly thorough to ensure all bases and loopholes are covered. Protocol required reiterating relevant terms and conditions and to do so in a way that left the divine-as-constructed no room for plausible deniability. Such was needed to present a case where the boundaries between the prosecution and the defence, the divine judge and the legal system, have become blurred, so much the more when taking the case straight to the accused who as the source of suffering, after allegedly revealing and doing so much, has caused cognitive dissonance by exercising the divine right to remain silent. Not much more could be done than obtain some communal satisfaction in presenting the logical problem as a theological one, expressed in the cathartic form of atheodicy.

\section{E CONCLUSION}

In this study, an original comparative-philosophical perspective on the nature, scope and function of the intended contradiction as logical status of beliefs about YHWH's divine attributes and relations to suffering was presented. This featured a discussion of concepts in Psalm 89 about YHWH's LPE-related attributes in relation to the deity's assumed relation to suffering in the world of the text. It was argued that not only could Psalm 89 be correlated and contrasted with counterpart concepts and correlation relations in the LPE, the nature, meaning and reference of its religious language and the reasoning in its religious thought could be fruitfully clarified also when described in terms of its relation to later philosophical-theological counterparts.

From the analysis, it may be concluded that Psalm 89 is clearly much more than even a contextually sensitive revised form of the LPE. On the one hand, some overlaps do occur. Examples include the logical problem that the Psalmist assumes emerges in the conjunction of certain beliefs about certain 
divine attributes and relations in suffering to others. The logical status of the religious language is clearly inclusive of paraconsistent propositional content in the reasoning used in the related religious thought running across the different literary forms in what was identified as belief sets A (vv. 2-38, 53) and B (3952). Nevertheless, as was demonstrated, the presuppositions, problems and perspectives associated with the LPE also differ from the counterpart concepts, concerns and categories in Psalm 89, particularly with reference to the nature and scope of divine attributes and relations, the suffering in view and with reference to the perceived ontological and axiological status of the logical problem. What in the LPE often ends as either theodicy or atheology is in Psalm 89 a deliberately and purposefully constructed atheodicy.

With this comparative-philosophical reading as an exclusive concern of the inquiry, this study offers an original and supplementary understanding of its contents. Extending what is usually limited to related piece-meal remarks in other varieties of biblical criticism, additional descriptive metaphysical and logical nuance and specificity could be added to existing attempts at theological restatements of Psalm 89's construction of suffering on its own terms, even if not in them. The chosen comparative-philosophical counterpart in the LPE thus reveals some of conditions of possibility that must be postulated as part of any attempted holistic understanding of why things in the world of the text are the way they are, or why they are at all.

\section{BIBLIOGRAPHY}

Adams, Robert Merrihew and Marilyn McCord Adams, eds. The Problem of Evil. Oxford: Oxford University Press, 1990.

Ahlström, Gösta. Psalm 89: eine Liturgie aus dem Ritual des leidenden Königs. Lund: Gleerups, 1959.

Auffret, Pierre. Merveilles à nos yeux: étude structurelle de vingt psaumes dont celui de 1 Ch 16,8-36. Berlin: Walter de Gruyter, 1995.

Barton, John. Ethics in Ancient Israel. Oxford: Oxford University Press, 2015.

Beebe, James R. "Logical Problem of Evil." No pages. The Internet Encyclopedia of Philosophy. Cited 4 November 2020. Online: https://iep.utm.edu/evil-log/.

Botha, Phil J. "Psalm 108 and the Quest for Closure to the Exile." Old Testament Essays 23/3 (2010): 574-596.

Brueggemann, Walter. Theology of the Old Testament: Testimony, Dispute, Advocacy. Minneapolis: Fortress Press, 1997.

Caquot, Andre. "Observations sur le Psaume 89.” Semitica XLI-XLII (1993): 133-158. Clifford, Richard J. "Psalm 89: A Lament over the Davidic Ruler's Continued Failure." Harvard Theological Review 73 (1980): 35-47.

Creach, John F.D. "The Mortality of the King in Psalm 89 and Israel's Postexilic Identity." Pages 237-249 in Constituting the Community, Studies on the Polity of Ancient Israel in Honor of S. Dean McBride Jr. Edited by John T. Strong and Steven S. Tuell. Winona Lake: Eisenbrauns, 2005. 
Crenshaw, James L. Defending God: Biblical Responses to the Problem of Evil. New York: Oxford University Press, 2005.

Crouch, Andy C. L. "Made in the Image of God: The Creation of the the Commissioning of the King and the Chaoskampf of YHWH." Journal of Ancient Near Eastern Religion 16/1 (2016): 1-21.

Cupitt, Don. After God: The Future of Religion. London: SCM Press, 1997. . Taking Leave of God. London: SCM Press, 1981.

Dumortier, Jean-Bernard. "Un Rituel d'Intronisation: le Ps LXXXIX 2-38." Vetus Testamentum 22 (2000): 176-196.

Floyd, Michael H. "Psalm 89: A Prophetic Complaint about the Fulfillment of an Oracle." Vetus Testamentum 42 (1992): 442-457.

Fretheim, Terrence E. The Suffering of God: An Old Testament Perspective. Philadelphia: Fortress Press, 1984.

Gerstenberger, Erhard S. "Theologies in the Book of Psalms." Pages 603-625 in The Book of Psalms. Edited by E S Gerstenberger. Leiden: Brill, 2005.

Gerstenberger, Erhard. S. and Wolfgang Schrage. Suffering. Translated by John E. Steely. Nashville: Abingdon, 1977.

Gericke, Jaco. 2018. “My Thoughts Are (not) Your Thoughts": Transposed SecondOrder Thinking in the Hebrew Bible." Journal for Semitics 27 (1): 16 pages. https://doi.org/10.25159/1013-8471/4217. . A Philosophical Theology of the Old Testament: A Historical, Experimental, Comparative and Analytic Perspective. London: Taylor and Francis, 2020.

Gibson, Arthur. Biblical Semantic Logic: A Preliminary Analysis. Oxford: Blackwell, 1981.

Hansson, Sven Ove. "Logic of Belief Revision." No pages in The Stanford Encyclopedia of Philosophy. Winter 2017 Edition. Edited by Edward N. Zalta. $\begin{array}{llll}\text { Cited } & 10 & \text { November } & 2020 .\end{array}$ https://plato.stanford.edu/archives/win2017/entries/logic-belief-revision/.

Hazony, Yoram. The Philosophy of Hebrew Scripture. Cambridge: Cambridge University Press, 2012.

Hick, John. Evil and the God of Love. Revised Edition. New York: Harper and Row, 1978.

Hossfeld, Frank-L "Psalm 89." Pages 576-601 in Psalmen 51-100. Edited by Frank-L Hossfeld, and Erich Zenger. Wien: Herder Verlag, 2000.

Hossfeld, Frank-L. "Ps 89 und das vierte Psalmenbuch (Ps 90-106)." Pages 173-183 in "Mein Sohn bist du" (Ps 2,7). Edited by E. Otto and E. Zenger. Stuttgart: Verlag Katholisches Bibelwerk, 2002.

Hossfeld, Frank-L and Erich Zenger. Psalmen 51-100. Übersetzt und ausgelegt. Herders Theologischer Kommentar zum Alten Testament. Freiburg-Basel-Wien: Herder Verlag, 2007.

Howard-Snyder, Daniel, ed. The Evidential Argument from Evil. Bloomington: Indiana University Press, 1996.

Human, Dirk. Psalms and Mythology. London: T \& T Clark, 2007.

Johnson, Dru. Biblical Philosophy. A Hebraic Approach to the Old and New Testaments. Cambridge: Cambridge University Press, 2021.

Johnson, Michael. "Comparative Philosophy." No pages. The Internet Encyclopedia of Philosophy. Cited 16 November 2020. Online: https://iep.utm.edu/composit/. 
Koch, Klaus. "Is There a Doctrine of Retribution in the Old Testament?" Pages 57-87 in Theodicy in the Old Testament. Edited by James L. Crenshaw. London: SPCK, 1993.

. Psalms 60-150. Hermeneia: Fortress Press, 1989.

Labuschagne, Casper J. "General Introduction to Logotechnical Analysis." No Pages. Cited 3 February 2010. Online: www.labuschagne.nl/aspects.pdf.

La Para, Nicholas. "Suffering, Happiness, Evil." Sophia 4 (1965): 10-16.

Mechon Mamre. Cited 17 November 2020. Online: https://www.mechon-mamre.org/.

Mitchell, Matthew W. "Genre Disputes and Communal Accusatory Laments: Reflections on the Genre of Psalm LXXXIX." Vetus Testamentum 55 (2005): 511-527.

Murphy, James. "Coherentism in Epistemology." No Pages. The Internet Encyclopedia of Philosophy. Cited 20 December 2020. https://iep.utm.edu/coherent/.

Pailin, David A. Groundwork of Philosophy of Religion. Philadelphia: Epworth Press, 1986.

Pardee, Dennis. "The Semantic Parallelism of Psalm 89." Pages 121-137 in In the Shelter of Elyon: Essays on Ancient Palestinian Life and Literature in Honor of G. W. Ahlström. Edited by Boyd W. Barric and J.R Spencer. Journal for the Study of the Old Testament Supplement Series 31. Sheffield: Sheffield University Press.

Plantinga, Alvin. God, Freedom, and Evil. New York: Harper and Row, 1974.

Prinsloo, Gert T.M. "Analysing Old Testament Poetry: An Experiment in Methodology with Reference to Psalm 126." Old Testament Essays 5/2 (1992): 225-251.

Prinsloo, Willem S. "Psalm 88: The Gloomiest Psalm?" Old Testament Essays 5 (1992): 332-345.

Ramond, Sophie. "La voix discordante du troisième livre du Psautier (Psaumes 74, 80, 89)." Biblica 96 (2015): 39-66.

Sarna, Nahum. "Psalm 89: A Study in Inner Biblical Exegesis." Pages 29-46 in Biblical and Other Essays. Edited by Alexander Altmann. Cambridge: Harvard University Press, 2013.

Schlesinger, George. "The Problem of Evil and the Problem of Suffering." American Philosophical Quarterly 1 (1964): 244-247.

Schmid, Konrad. A Historical Theology of the Hebrew Bible. Grand Rapids: Wm. B. Eerdmans, 2019.

Smith, Mark S. God in Translation: Deities in Cross-cultural Discourse in the Biblical World. Forschungen zum Alten Testament Series I. Vol. 57. Tübingen: Mohr Siebeck, 2008.

. "Monotheism and the Redefinition of Divinity in Ancient Israel." Pages 278293 in The Wiley Blackwell Companion to Ancient Israel. Edited by Susan Niditch. Oxford: Wiley-Blackwell, 2015.

Steymans, Hans-Ulrich. "Deinen Thron habe ich unter den grossen Himmeln festgemacht." Die formgeschichtliche Nähe von Ps 89,4-5.20-38 zu Texten vom neuassyrichen Hof. Pages 184-251 in "Mein Sohn bist du” (Ps 2,7). Studien zu den Königspsalmen. Edited by Eckart Otto and Erich Zenger. Stuttgart: Verlag Katholisches Bibelwerk, 2002.

Stump, Eleonore. "Knowledge, Freedom and the Problem of Evil." International Journal for Philosophy of Religion 14 (1983): 49-58 
Swinburne, Richard. "Does Theism Need a Theodicy?" Canadian Journal of Philosophy 18 (1988): 287-312.

. "Some Major Strands of Theodicy?" Pages 30-48 in The Evidential Argument from Evil. Edited by Daniel Howard-Snyder, Bloomington: Indiana University Press, 1996.

Tambasco, Anthony J. The Bible on Suffering: Social and Political Implications. New York, Manwah: Paulist, 2001.

Tate, Marvin E. Psalms 51-100. Word Biblical Commentary 20. Dallas: Word Books, 1991.

Temple, William. A Logical Analysis of Twentie Select Psalms. London: Felix Kingston, 1605.

Thompson, Thomas L. The Bible in History: How Writers Create a Past. London: Jonathan Cape, 1999.

Van Inwagen, Peter. The Problem of Evil. Oxford: Oxford University Press, 2006.

Veijola, Timo. "Davidverheißung und Staatsvertrag. Beobachtungen zum Einfluss altorientalischer Staatsverträge auf die biblische Sprache am Beispiel von Psalm 89." Zeitschrift für die Alttestamentliche Wissenschaft 95 (1983): 9-31.

Venter, Pieter M. "Psalm 89 and Daniel 7." Old Testament Essays 17/4 (2004): 678691.

Ward, Keith. Concepts of God: Images of the Divine in the Five Religious Traditions. Oxford: Oneworld Publications, 1998.

Ward, James M. "The Literary Form and Liturgical Background of Psalm LXXXIX." Vetus Testamentum 11 (1961): 321-339.

Williams, Ronald J. "Theodicy in the Ancient Near East." Pages 42-56 in Theodicy in the Old Testament. Edited by James L. Crenshaw. London: SPCK, 1993.

Wong, David. "Three Kinds of Incommensurability." Pages 140-159 in Relativism: Interpretation and Confrontation. Edited by Michael Krausz. Notre Dame: Notre Dame University Press, 1989.

Jaco Gericke, Associate Research Professor in Ancient Culture, Faculty of Theology, North-West University, Vanderbijlpark, South Africa. Email: 21609268@ nwu.ac.za ORCID: https://orcid.org/0000-0002-1304-7751. 